\title{
When Common Interests Are Not Common: Why the Global Basic Structure Should be Democratic
}

Andreas Føllesdal

University of Oslo

Follow this and additional works at: https://www.repository.law.indiana.edu/ijgls

Part of the Constitutional Law Commons, International Law Commons, and the Law and Politics

\section{Commons}

\section{Recommended Citation}

Føllesdal, Andreas (2009) "When Common Interests Are Not Common: Why the Global Basic Structure Should be Democratic," Indiana Journal of Global Legal Studies: Vol. 16 : Iss. 2 , Article 9.

Available at: https://www.repository.law.indiana.edu/ijgls/vol16/iss2/9

This Symposium is brought to you for free and open access by the Law School Journals at Digital Repository @ Maurer Law. It has been accepted for inclusion in Indiana Journal of Global Legal Studies by an authorized editor of Digital Repository @ Maurer Law. For more information, please contact rvaughan@indiana.edu.

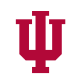

JEROME HALL LAW LIBRARY

INDIANA UNIVERSITY

Maurer School of Law
Blooming ton 


\title{
When Common Interests Are Not Common: Why the Global Basic Structure Should Be Democratic
}

\author{
Andreas Føllesdal*
}

\begin{abstract}
The global constitution-the fundamental international norms and structures that serve constitutional functions - should include mechanisms of democratic contestation and accountability. This central claim of global constitutionalism faces three objections extrapolated from arguments made by Andrew Moravcsik and Giandomenico Majone in debates about the democratic deficit of the European Union (EU): the global constitution only regulates issues of low salience for citizens; democratic control is explicitly counter to the self-binding system that international regulations aim to achieve; and the EU's track record suggests that democratic control at the international level may be unnecessary to ensure congruence between voters' preferences and actual regulations. These objections miss the profound impact of the global constitution and the complexity of the "common goods" that multilevel regulations are meant to secure. They also overlook some of the reasons to value democratic deliberation and contestation as mechanisms to enhance the trustworthiness of institutions and authorities.
\end{abstract}

* Professor, Director of Research, Norwegian Centre for Human Rights, University of Oslo. I am grateful for comments on a draft presented at a Workshop on Global Constitutionalism: Process and Substance, Kandersteg, Switzerland, January 19, 2008. The Ash Institute for Democratic Governance and Innovation at the Kennedy School of Government, Harvard University graciously provided opportunities to revise that draft. I am also thankful for support from the European Union's Integrated Project on New Modes of Governance (NEWGOV) and from the Norwegian Centre of Excellence on the Study of Mind in Nature. Earlier work on this topic has benefited from the CONNEX workshops at Katholieke Universiteit Leuven, Belgium and The Hague, The Netherlands, a NEWGOV Integrated Project workshop in Florence, Italy, and from audiences at a European Consortium for Political Research conference in Budapest, Turkey.

Indiana Journal of Global Legal Studies Vol. 16 \#2 (Summer 2009)

(9Indiana University Maurer School of Law - Bloomington 


\section{INTRODUCTION}

Should core constitutional principles of democracy, human rights, and the rule of law be brought to bear on the international legal order? That is, can global constitutionalism be defended?' This article defends one of global constitutionalism's central claims: the global constitution-the fundamental international norms and structures that serve constitutional functions--should include mechanisms of democratic contestation and accountability. It is inconsistent to hold that domestic authorities should be democratically accountable while the authorities who shape and maintain the global constitution should not. This inconsistency is significant in that the global constitution has a greater distributive impact, and those who shape it have larger margins of discretion, than is sometimes claimed. Although the global constitution's influence over individuals is often opaque and mediated by states and domestic institutions, it raises fundamental issues of normative legitimacy. Subjects have less of a moral obligation to comply with global rules and regulations when they do not have a fair share of power over how to shape and change them.

Part I of this article presents some central challenges to calls for a more democratic global political order. The next parts lay out central discussions of the case for democratizing the global constitution and responses to objections. Part II summarizes the complex impact of global, multilevel regulations. Part III considers the various forms of common interests pursued by governments through such regulations. The European Commission is also discussed to illustrate how the concept of a global constitution has been blurred and how democratic measures may help. Part IV sketches a general case for democratic contestation and accountability. Finally, Part V draws on the material in the previous parts to rebut the three arguments against a more democratic global constitution.

The pattern of rules and practices of domestic and international institutions interact in profound ways that have pervasive effects on the distribution of benefits and burdens within and across state borders. As a whole, this global basic structure enables mutually beneficial cooperation ranging from material benefits of domestic and international trade to rules of non-intervention and other principles of international law. Notwithstanding these benefits, the present global basic structure also contributes to injustices, including those wrought by unfair trade practices and unwarranted international disregard for domestic human rights violations and oppressive dictators. The domestic and international rules could avoid such disadvantages

1. Anne Peters, Compensatory Constitutionalism: The Function and Potential of Fundamental International Norms and Structures, 19 LEIDEN J. INT'L L. 579, 583 (2006). 
by yielding other distributions of benefits and burdens among individuals. Indeed, other global basic structures might not even include sovereign states as we know them, but rather cluster and bundle legal authority and immunity in different configurations. For example, a world order akin to a global confederation as Immanuel Kant urged, ${ }^{2}$ or one of insulated states as Jean-Jacques Rousseau favored. ${ }^{3}$ A crucial question then follows: what normative objectives and standards should regulate the global basic structure as a whole? This issue can be further refined. Given that we live in a system of states, should the international rules and institutions that regulate their interaction be subject to democratic control by individuals, or does it suffice that democratic states have granted their consent? Some further comments about the role of states in the present global basic structure are appropriate at this point.

We now live in a system of states where state governments and state borders are central forces that shape and constrain the rules and actors of political, social, and economic interaction. But state borders do not completely contain these rules, and actors other than individual states affect them. An obvious and extreme case can be found in how the rules of the EU regulate its citizens and member states. This international order is aptly described by David Held:

[A]n international order involving the conjuncture of: dense networks of regional and global economic relations which stretch beyond the control of any single state (even of dominant states); extensive webs of transnational relations and instantaneous electronic communications over which particular states have limited influence; a vast array of international regimes and organizations which can limit the scope for action of the most powerful states; and the development of a global military order, and the build-up of the means of "total" warfare as an enduring feature of the contemporary world, which can reduce the range of policies available to governments and their citizens. ${ }^{4}$

Many of the significant rules of the international order are part of what Anne Peters calls "global (or international) constitutional law." She describes global consti-

2. Immanuel Kant, Idea for a Universal History with a Cosmopolitan Purpose, in Kant's Political Writings 41, 41-53 (Hans Reiss ed., H. B. Nisbet trans., 1st ed. 1970).

3. See Stanley Hoffmann, Rousseau on War and Peace, in The State of War 54, 62 (1965).

4. David Held, Democracy and the Global Order: From the Modern State to Cosmopolitan Governance 20 (1995). 
tutional law as "the most important norms which regulate political activity and relationships in the global polity (consisting of states and other subjects of international law)." Its rules and practices include, inter alia, the treaties and practices that define sovereignty, the rules of the World Trade Organization, and erga omnes obligations.

The present global basic structure is thus not a set of sovereign states. Rather, it is a system of "multilevel governance" where states and other actors enjoy several forms of decision-making. "Multilevel" has many different meanings; ${ }^{6}$ here it refers to the vertical dispersal of political authority from the state upward to the supranational level and downward to subnational levels with complex forms of interplay. Multilevel also refers to the horizontal dispersal of authority whereby non-state actors participate in rule formulation and implementation.

The term governance likewise has multiple uses. ${ }^{7}$ Government occurs when organizations, typically states, govern or regulate issue areas mainly through hierarchical control in the shadow of coercion. In contrast, organizations exercise governance when they come together to regulate without formal hierarchy or coercion. In such instances, governments consent to a vast collection of rules ranging from treaties to nonbinding resolutions that form the global constitution. These mechanisms of consensus or consent "may or may not derive from legal and formally prescribed responsibilities and... do not necessarily rely on police powers to overcome defiance and attain compliance."

Unlike government, governance is not held to democratic standards. Yet many regard governance and the present global constitution as normatively legitimate. One reason may be that the procedures and rules of governance are based on and respect state sovereignty and autonomy without operative threats of coercive force. That is, the global constitution is based on mutual consent among states, many of which are democratic. This raises an important question: is democratic accountability therefore an inappropriate standard for global constitutional law?

The answer to this question can be formed in response to three objections, extrapolated from debates about the democratic deficit of the European Union

5. Peters, supra note 1 , at 582.

6. See Liesbet Hooghe \& Gary Marks, Unravelling the Central State, but How? Types of Multilevel Governance, 97 A м. Pol. Sci. Rev. 233, 233-34 (2003).

7. See, e.g., Commission on Global Governance, Our Global Neighrourhood 2-5 (1995); Commission of the European Communities, European Governance: $A$ White Paper, COM (2001) 428 final (July 25, 2001).

8. James N. Rosenau, Governance, Order, and Change in World Politics, in Governance Wirhout Government: Order and Change in World Politics 1, 4 (James N. Rosenau \& Ernst-Otto Czempiel eds., 1992). 
(EU). These objections do not consider the profound impact of the global constitution and the complexity of the common goods that multilevel regulations are meant to secure. They also overlook some of the reasons to value democratic deliberation and contestation as mechanisms that enhance the trustworthiness of institutions and authorities.

\section{The Case Against Democratic Global Constitutional Law}

Domestically, democratic accountability is often regarded as a sine qua non for legitimate rule that imposes undesirable or inescapable effects on some citizens for the benefit of others. Many extrapolate this democratic intuition to global constitutional law, for instance, in the form expressed by global constitutionalism. One reason may be that we find it conceptually difficult to disentangle legitimacy and democracy. That is, we believe that legitimate modes of governance must be democratically accountable. This entanglement has been described as follows: "In our Western view, only democratic systems, advocating the values of liberty, equality and community, deserve the loyalty of the citizens. Hence, the notions legitimacy and democratic legitimacy must be considered as interchangeable ...."9

This conflation of legitimacy and democracy, and the presumption in favor of democracy merit, challenge and scrutiny. Must multilevel regulation of the kind expressed in present global constitutional law be subject to more direct democratic control? If so, why, if international regulations are the result of treaties freely agreed upon by sovereign parties with whatever domestic normative legitimacy they might have? What is the value added by citizens' consent through democratic contestation for regional or international authorities?

These questions raise fundamental issues about standards of legitimacy appropriate for the global order and for multilevel political orders in general. What normative standards should be brought to bear on institutions beyond the state individually or for the global constitution as a whole? And how might democratic rule, in particular, contribute to make such multilevel governance more normatively legitimate? The debate about the alleged democratic deficit of the EU may serve as a heuristic device to formulate answers to the aforementioned questions. This does not suggest that the debate can be simply transposed or generalized wholesale, as the EU has unique competences and its member states exercise prominent, complex control. Yet the strongest arguments against a more demo-

9. Koen Lenaerts \& Marlies Desomer, New Models of Constitution-Making in Europe: The Quest for Legitimacy, 39 Соммом Мкт. L. Rev. 1217, 1220 n.15 (2002). 
cratic EU could also be applied against a more democratic global constitution. And arguments in support of the EU being governed more democratically may support the case for global constitutionalism.

As previously mentioned, many have claimed that the EU suffers from a democratic deficit. ${ }^{10}$ However, reasoned objections dismiss this diagnosis. Andrew Moravcsik asserts that international organizations generally, and the EU in particular, do not require much in the way of direct democratic legitimacy." Giandomenico Majone has further argued that increased democratic accountability would be detrimental to the objectives of the EU. These arguments have stimulated wide-ranging debates, ${ }^{12}$ and at least three objections to a more democratic global constitutionalism can be extrapolated from them.

\section{A. The Low Impact of Global Constitution Within the State}

One objection is that the global constitution's impact within the state is low. This objection arises from the claim that international organizations, including the EU, only address issue areas that are of low or no salience to voters, such as the removal of non-tariff barriers. ${ }^{13}$ In contrast, the issues that voters are concerned with-fiscal policies, social welfare, education, and culture-remain the domain of domestic, democratic authorities. Thus, to subject the policies of international organizations to political contestation will neither get voters' attention nor affect any policy changes of concern to them.

\section{B. The Objectives of Multilevel Regulation Prohibit Democratic Accountability}

The second objection is based on the assertion that a central objective of international organizations in general, and the EU in particular, is actually to insulate certain decisions from democratic contestation. Majone argues that the $\mathrm{EU}$ is best regarded as a "regulatory state" whose objective is Pareto efficient outcomes,

10. See generally Andreas Føllesdal, Survey Article: The Legitimacy Deficits of the European Union, 14 J. Pol. PhIL. 441 (2006).

11. See Andrew Moravcsik, Is There a "Democratic Deficit" in World Politics? A Framework for Analysis, 39 Gov'r \& Opposition 336, 347 (2004).

12. Andreas Føllesdal \& Simon Hix, Why There is a Democratic Deficit in the EU: A Response to Majone and Moravcsik, 44 J. Coмmon Mкт. Stud. 533, 534-37 (2006).

13. Moravcsik, supra note 11 , at 360 . 
rather than redistributive solutions or outcomes that create losers. ${ }^{14}$ International agencies help resolve collective action problems when each party is tempted to free ride. And governments can use international obligations to bind their own hands, so that their voters will not sacrifice important longer-term objectives for the sake of myopic short-term goals.

\section{Multilevel Democracy is Unnecessary for Preference-Policy Congruence}

The final objection can be found in Moravcsik's argument that the track record of the EU shows that its policies are in fact close to the preferences of the median voter and, as a result, complaints about unelected, undemocratic bureaucrats and executives being nonresponsive are at best overblown. Thus, the constitution-like checks and balances and the democratic control exercised within member states serve to bring EU policies in line with the preferences of the average voter.

To present the case for democratic global constitutionalism and to respond to these objections, the following parts address three central topics: the impact of the current global constitution and its various forms of multilevel regulation, the common interests that multilevel organizations promote, and the reasons for valuing democratic deliberation and contestation as mechanisms to enhance the trustworthiness of institutions and authorities.

\section{The Distributive Impact of International Organizations}

The global constitution has a massive impact on individuals, particularly on their life plans and opportunities. The impact is often indirect and surreptitious. Brief discussion of the reasons for such an impact and its implications follow.

First, recall that sovereign states are "socially constructed" by norms of the global constitution. This particular configuration of legal powers and immunities has allowed inhabitants to pursue their interests with fewer fears of intervention and domination by external actors, except when there are intergovernmental agreements that provide for such intervention. On the other hand, "tall" state borders have also served to reduce inhabitants' chances of obtaining foreign assistance when opposing abusive leaders.

Within the international arena, treaties bind states in several ways. Binding

14. Giandomenico Majone, A European Regulatory State?, in European Union: Power and Policy-Making 263-77 (Jeremy Richardson ed., 1st ed. 1996); Giandomenico Majone, The Rise of the Regulatory State in Europe, W. Eur. PoL., July 1994, at 77. 
U.N. Security Council Chapter VII resolutions commit all domestic and EU legal systems. Some international authorities have the power to make decisions with direct and sometimes obvious effects on individuals. ${ }^{15}$ For example, decisions of the World Trade Organization's Dispute Settlement Body have global ramifications for business operators and citizens. Likewise, the U.N. Security Council's "smart sanctions" are directed at specific individuals, businesses, or groups of persons. ${ }^{16}$

International regulations also have profound, but less visible, impacts when they affect the opportunity space of national authorities, often by placing it beyond parliamentary control. Consider the complex areas in which WTO regulations and non-state financial trade association regulations are heavily involved: ${ }^{17}$ immigration rules, regulation of the banking sector, ${ }^{18}$ and foreign investments or Internet. ${ }^{19}$ The benefits of larger markets and reduced transaction costs should not be ignored. Still, many affected consumers and other concerned citizens are of ten effectively excluded from participation and insight, even though the opportunities and benefits will favor only some of them. Others may suffer a loss of relative bargaining power due to the regulatory details or from open borders or global markets. For instance, less economically developed states face new risks of a "race to the bottom" when their strongest comparative advantages in the competition for multinational corporations are lax human rights protections for workers and communities.

The impact on states' maneuvering room can hardly be overestimated. The increased interdependence and trade among states have curtailed and even removed many of the economic and political instruments that governments could previously use to protect citizens from external shocks. Other states and non-state actors can now impact citizens of other states in ways that their own government no longer can. ${ }^{20}$ Thus, the extensive, complex interdependence among states re-

15. Ramses Wessel \& Jan Wouters, The Phenomenon of Multilevel Regulation: Interactions Between Global, EU, and National Regulatory Spheres, in Multilevel Regulation and the EU 9, 14-15 (Andreas Føllesdal et al. eds., 2008).

16. See Iain Cameron, UN Targeted Sanctions, Legal Safeguards and the European Convention on Human Rights, 72 Nordic J. INT'L L. 159, 159-60 (2003).

17. See generally Caroline Bradley, Financial Trade Associations and Multilevel Regulation, in Multilevel Regulation And the EU, supra note 15, at 73.

18. See generally Bart De Meester, Multilevel Banking Regulation, in Multilevel Regulation AND THE EU, supra note 15, at 101.

19. See generally Robert Uerpmann-Wittzack, Multilevel Internet Governance Involving the European Union, Nation States and NGOs, in Multilevel Regulation and THE EU, supra note 15, at 145.

20. See John G. Ruggie, Taking Embedded Liberalism Global: The Corporate Connection, in TAMing Globalization 93, 93-94 (David Held \& Mathias Koenig-Archibugi eds., 2003). 
duces the value of sovereignty in the sense of legal immunity from foreign influence. Indeed, as states increasingly engage in vertical multilevel governance, sovereignty changes from being a constitutive feature of states to a set of bargaining chips by which states pool decision-making authority in various sectors. ${ }^{21}$ The result is a drastic reduction in the worth of domestic, democratic mechanisms.

The value of domestic democratic arrangements is further attenuated by horizontal multilevel governance in which the role of the state changes from having a quasi-monopoly on political authority to being in charge of integrating partly privatized, partly internationalized authorities. The state must initiate, coordinate, and synthesize the conduct of many different international and private actors. ${ }^{22}$ Often the national domestic authorities are left with little or no influence. Consider the international regulation of technical requirements for the registration of pharmaceuticals. ${ }^{23}$ The laudable aim is to speed up development and registration of new medicines to benefit patients and companies. However, only the latter take part in the processes that lead to regulations. Unelected industry experts with technical expertise, but no democratic authority, exercise great influence on regulatory decisions. ${ }^{24}$ There is little transparency or democratic oversight by patients, public payers, or other actors. As a result, these regulations become de facto international standards and are incorporated into national law without much scrutiny, even though they override competing national regulations.

Oftentimes the multilevel system skews power toward the executive and away from the legislative branch. For example, the decision rules of the EU typically reduce the ability of national parliaments to exercise their legislative authority and oversight over the executive branch. ${ }^{25}$ This situation is aided by various permutations of two-level diplomacy. These brief discussions show that international institutions, organizations, and regimes affect the allocation of benefits and burdens among individuals. The upshot is that the present global constitution creates a

21. Robert O. Keohane, Hobbes's Dilemma and Institutional Change in World Politics: Sovereignty in International Society, in Whose World Order? Uneven Globalization and the End of the Cold WAR 165, 177 (Hans-Henrik Holm \& Georg Sørensen eds., 1995).

22. Philipp Genschel \& Bernhard Zangl, Transformations of the State-From Monopolist to Manager of Political Authority 1-2 (Transformations of the State, Working Paper No. 076, 2008), available at http://www.sfb597.unibremen.de/pages/download.php?ID $=90 \&$ SPRACHE $=$ en $\&$ TABL $\mathrm{E}=\mathrm{AP} \& \mathrm{TYPE}=\mathrm{PDF}$.

23. See generally Bärbel R. Dorbeck-Jung, Challenges to the Legitimacy of International Regulation: The Case of Pharmaceuticals Standardisation, in Multilevel Regulation and the EU, supra note 15 , at 51 .

24. Id. at 65 .

25. See Føllesdal \& Hix, supra note 12, at 535. 
system of states, albeit one that is strongly modified by several forms of multilevel governance. Actors and rules beyond a state's political authorities may enhance justice and well-being for the state's citizens; however, these same actors and rules may also prevent, bolster, skew, or otherwise hamper elected, accountable authorities. Thus, the global constitution raises important questions concerning normative legitimacy and the right of authorities to expect compliance. Domestically, the distributive impact of laws and policies gives rise to claims that they should be subject to popular scrutiny and control in the form of human rights protections and mechanisms of democratic accountability. The impact of the global constitution, both on individuals and on their state governments, should yield the same conclusion at the global level. Global constitutional law should include mechanisms of democratic accountability. Some have responded that, at least in the case of the EU, such accountability would be unnecessary at best and severely hinder the common interests it was created to secure. Do these arguments against democracy in the EU and global constitutional law hold up against scrutiny? This question requires us to initially consider why democratic accountability may be contrary to individuals' common interests.

\section{The Confusing Interpretations of "Common Interests," Illustrated by the European Commission}

It is close to a truism that agreements among informed, free parties will be in their common interest. That is, parties will not enter into a binding agreement unless each stands to benefit from it. To secure such benefits, it may be defensible at times for a democracy to bind its own hands in ways that a later majority cannot easily unbind. In the case of the EU, two distinct cases can be discerned. After briefly outlining them, I will address the broad range of other decisions that are arguably best made by international bodies. However, these other decisions may well be subject to democratic contestation without great loss.

Some citizen interests clearly support the supremacy of common decisions at the EU level. A central authority beyond the control of any individual or state government can help resolve two kinds of collective action problems. First, one disadvantage of democratically accountable authorities is that the competition for votes tempts politicians to pursue policies that are in citizens' short-term interest but detrimental in the long run. Such concerns support "nondemocratic" agencies such as an independent central bank. Second, a central authority may be necessary to secure general compliance with policies that reap benefits only when all 
comply. Thus, governments have delegated authority over certain regulatory policies to the EU, such as a single market, product standards, and health and safety rules. Governments in each country would otherwise be tempted to default in order to win domestic votes. The common interest in resolving such collective action and free-rider problems should trump the "egoistic" member state preferences on these topics, even when the electorates have similar preferences.

Majone argues that the need for such common interest decisions precludes a more democratic EU, noting that one of the justifications for the creation of the EU was the avoidance of the collective action problems that democracy cannot resolve. ${ }^{26}$ In response, I agree that there may be good reasons to keep certain policy decisions away from the ordinary election cycle, and, instead to give them to bodies like independent banks, courts, and agencies that ensure fair competition. But the number of policy decisions to which this would apply may be fewer than one may think. Moreover, I assert that there are many other common interests that the EU and other international organizations can and do promote and which democratic contestation does not threaten. To the contrary, identifying these common interests and ensuring their promotion requires something similar to democratic deliberation and accountability. And these regulations in pursuit of common interests should not always override domestic, democratic preferences.

It is an open question whether those interests that citizens have in common are best served by common policies at the EU or at some other level. Consider that we all have similar interests in goods for sustenance, security, and welfare. Some of these may be best provided by the individual, others by a family, and still others by one's state, or, arguably, by organizations above the state. As a result, a determination must be made as to which level of political organization should be authorized to secure these various interests. A decision about which of these regulations should have priority in cases of conflict is also required; it would be slipshod to hold that policies that aspire to regulate a larger area should always take precedence, regardless of the nature of the interests they secure. In the case of the EU, some regulations create benefits of scale, resolve coordination problems, and even create new goods that might be of value, such as a unified voice as a world actor. Yet some of these gains may be less important to individuals or their states than the losses that a particular regulation may inflict.

To make some headway on how to think about these issues and Majone's arguments, we must first take a closer look at how Pareto improvements impact in-

26. See Giandomenico Majone, Europe's "Democratic Deficit": The Question of Standards, 4 Eur. L.J. 5, 16-18 (1998). 
dividuals. This is necessary because regulations that improve the situation of some without leaving anyone worse off may raise issues of distributive justice and fair decision-making. There are at least four reasons for such issues.

Often there are different ways to improve the situation relative to the status quo. One distributive issue addresses which of the improvements to implement, since any choice will benefit some more than others. This holds true for a wide variety of regulations that are allegedly in the interest of every signatory. Consider the conflicts concerning details of the World Trade Organization and the regulation of pharmaceuticals, the accounting standards of the Basel Committee versus those of the International Accounting Standards Board, ${ }^{27}$ or the conflicting definitions of terrorism by the United Nations and regional bodies. ${ }^{28}$

Second, due to the complex interdependence of states, ${ }^{29}$ many Pareto-improving regulatory and policy decisions may affect other policy areas. Multilevel regulation is typically issue specific, and initially, the various authorities are not harmonized with regard to competence or authority. The spillover effects may be drastic. Consider the alleged impact of free market policies in the EU on member states' abilities to maintain social welfare arrangements. These spillover effects raise challenging concerns about effective and legitimate coordination. ${ }^{30}$ Solutions typically include limiting the number of actors while making them multipurpose or reducing the interaction between them. The latter is difficult when states jointly seek to regulate a wide range of issue areas, while the former increases the need for normatively justifiable mechanisms of conflict resolution. We may be witnessing the latter in the increased concerns about a legitimacy crisis of the EU. Its objectives have increased, ranging from securing peace, which is close to a public good in the economists' sense, to the long list enumerated in the Lisbon Treaty, ${ }^{31}$ which includes the well-being of its peoples, freedom, security, a single market, sustainable development, and a social market economy aimed at full employment. ${ }^{32}$ The objectives and policies may be laudable and appropriate for the

27. See generally De Meester, supra note 18.

28. Erling Johannes Husabø, The Interaction between Global, Regional and National Regulation in the Definition of Terrorism, in Multilevel Regulation and the EU, supra note 15, at 169.

29. See genetally Robert O. Keohane \& Joseph S. Nye, Power and Interdependence 20-32 (3d ed., Longman 2001) (1977).

30. Hooghe \& Marks, supra note 6, at 239.

31. Treaty of Lisbon Amending the Treaty Establishing the European Union and the Treaty Establishing the European Community art. 2, Dec. 13, 2007, O.J. (C 306) 1 [hereinafter Lisbon Treaty].

32. Lisbon Treaty art. 2. 
EU, but they are unordered, vague, and create dilemmas. Their all-important details, relative weights, and limits remain obscure and contested. Indeed, they are the stuff of political contestation among parties and ideologies within member states. The EU must address such conflicts about interdependent regulations in a sufficiently responsive and transparent way. We witness similar tensions with respect to the global constitution. The coordination problem among regulatory regimes is addressed below as the "fragmentation of international law." 33

Third, the multilevel regulations may well be Pareto improvements in the sense that they can benefit every signatory state, but still not benefit each individual. Even though each state gains, some individuals and segments may lose. The increased international interdependence outlined in Part I renders more governments unable or unwilling to compensate their losers. Thus the new regulation has an obvious distributive impact that merits normative concern for the domestic government and other authorities that create and maintain the global constitution.

Fourth, note that many EU regulations are not Pareto improvements. Consider interest rate policies, market "de"regulations detrimental to some producers for domestic markets, and EU expenditure policies that only benefit certain depressed regions or targeted groups while imposing burdens on others. ${ }^{34}$ Presumably, the best defense of such regulations is that the unit of assessment should not be a single policy, but rather the set of regulations as a whole. It is this package that is a Pareto improvement, compared to the lack of common regulation. This response underscores the distributive impact even of Pareto improvements and the need for decision-making procedures to ensure that complex package deals and short-term sacrifices by some member states and citizens do, in fact, even out over time. Thus, the common interest in a regional or global authority does not remove distributive concerns, but rather highlights the need for acceptable decision-making procedures for selecting policies and combinations thereof.

The upshot of these comments is that the notion of common interests should not lead us to dismiss the need for democratic accountability and control over those bodies that are authorized to make laws and regulations. Even in the ab-

33. See generally International Law Commission, Study Group of the International Law Commission, Fragmentation of International Law: Difficulties Arising from the Diversification and Expansion of International Law, Report of the Study Group of the International Law Commission, Addendum, Appendix, Draft Conclusions of the Work of the Study Group, U.N. Doc. A/CN.4/L.682/Add (May 2, 2006) (finalized by Martti Koskenniemi).

34. Føllesdal \& Hix, supra note 12, at 543; see generally Christian Joerges, Der Philosoph Als Wahrer Rechtslehrer, 5 Eur. L.J. 147 (1999) (reviewing Giandomenico Majone, Regulating EuROPE (1996). 
sence of redistributive arrangements, a wide range of regulations have significant impact on the lives and opportunities of individuals. The changing role of the European Commission can be used to illustrate some of the challenges and possible strategies to alleviate them, including increased democratic accountability.

\section{A. The Case of the European Commission}

The European Commission has had a legal monopoly on legislative proposals in the EU. This is presumably due to its mandate to "promote the general interest of the Union and take appropriate initiatives to that end." ${ }^{35}$ Those who prize a politically independent and depoliticized EU may worry that recent reductions in European Commission independence will politicize it at the cost of its credibility. According to the Lisbon Treaty, the European Parliament will be charged with electing the Commission President. ${ }^{36}$ What are we to make of these risks of politicization? ${ }^{37}$

The Lisbon Treaty, as those before it, skirts crucial issues about the nature of the interests the EU is to pursue. "The Union shall have an institutional framework which shall aim to promote its values, advance its objectives, serve its interests, those of its citizens and those of the Member States. ${ }^{13}$ However, the interests of EU citizens are not automatically best served by granting legal supremacy to all EU-level regulations aimed to secure "the European interest."

Given the European Commission's institutional mandate, there is a very real risk that the Commission may misinterpret all objections by member states as expressions of inappropriate concern for national interests. Such a bias is clear in the 2001 White Paper on Governance issued by the European Commission. ${ }^{39}$ In the document, the Commission offers only one diagnosis of existing disagreements: that the intergovernmental Council of Ministers inappropriately pursues sectoral, national interests. ${ }^{40}$ The White Paper ignores other, more legitimate reasons for deadlock. One reason might be that governments foresee citizens of one

35. Lisbon Treaty art. 9D.1.

36. Lisbon Treaty art. 9A.1.

37. See Giandomenico Majone, State, Market and Regulatory Competition in the European Economy, in Centralization or Fragmentation? Europe Facing the Challenges of Deepening, Diversity, And Democracy 94, 121 (Andrew Moravcsik ed., 1998).

38. Lisbon Treaty art 9.1 .

39. Commission of the European Communities, supra note 7, at 29; see Andreas Føllesdal, The Political Theory of the White Paper on Governance: Hidden and Fascinating, 9 Eur. PUB. L. 73, 79-81 (2003).

40. See Commission of the European Communities, supra note 7, at 29-30. 
or more member states suffering unacceptably large losses as the result of a proposed measure. It is therefore implausible to assume that the Commission is best suited to make legislative proposals on the basis of its judgment about the general interests of the EU. National protests and appeals to national interest should not always be dismissed as illegitimate. To the contrary, the Commission's contested conception of the interests of the EU, its member states, and citizens should not always overrule protests.

At least three strategies to reduce the risk of bias in EU regulations are worth mentioning. One strategy is to remove the monopoly on regulatory decision-making, so that other EU bodies can also propose regulations. A second strategy is to implement a new procedure, first introduced in the draft constitutional treaty and kept in later modifications. ${ }^{41}$ Under the procedure, the parliaments of member states can gain access to legislative proposals and appeal them if the parliaments suspect that the proposals violate the principle of subsidiarity. This principle holds that "the Union shall act only if and insofar as the objectives of the proposed action cannot be sufficiently achieved by the Member States, either at central level or at regional and local level, but can rather, by reason of the scale or effects of the proposed action, be better achieved at Union level. ${ }^{342}$ This mechanism may facilitate important public discussion and deliberation about the objectives and alternative means available to member states and the European Union. Such discussions may also be crucial to citizens' long-term support for the political order, and thus to the authorities' ability to govern.

The third strategy is to politicize the Commission through "parliamentarism," whereby the European Parliament elects the Commission President. This may secure more transparent and representative Commission decisions on such contested issues. Will this politicization threaten the credibility of the Commission as Majone fears? There is indeed a risk that some of the member states will refuse to collectively bind themselves and that, as a result, some decisions will be overturned prematurely. On the other hand, democratic contestation and deliberation does promise to make some of the distributive issues and actual choices more transparent, and this may be important to assure citizens and member states that the Commission does indeed promote their general interests, and does so in a defensible and responsive way.

Consider, for instance, the European Parliament's rejection of European Commission President Jose Manuel Barroso's first slate of commissioners in 2004.

41. Lisbon Treaty art. 3B.

42. Lisbon Treaty art. 3B.3. 
European Parliament members objected to proposed Commissioner of Justice and Home Affairs Rocco Buttiglione for his alleged views concerning homosexuals and women. This protest assured the European public that its votes for Members of European Parliament could affect the composition and policies of the Commission, and that the rules provide a certain degree of responsiveness of elected representatives to the interest of citizens. Such responsiveness and assurance are crucial contributions of democratic procedures.

In order to address the objections to democratizing global constitution law, we must finally consider several reasons to value democratic contestation, deliberation, and accountability, reasons that are often overlooked.

\section{Fragments of a Theory of Democracy}

Leaving details aside for our purposes, let us here regard democracy as a set of institutionally established procedures that regulate ${ }^{43}$ competition for control over political authority on the basis of deliberation, where all or almost all adult citizens may participate in an electoral mechanism, and whereby their expressed preferences over alternative candidates determine the outcome in such ways that the government is accountable to, and thereby responsive to, all or as many as possible.

The best argument for democratic decision-making is that democratic rule is, over time, more reliably responsive to the best interests of the members of the political order. ${ }^{44}$ These interests include basic needs and a fair share of additional goods and burdens. These goods should include a share of political influence over the institutions that in turn shape individuals' opportunities and choices.

Democracy is arguably the institutional arrangement that most reliably prevents risks to individuals' vital needs and secures a just distribution of other goods. Amartya Sen has argued that freedom of the press and democratic competition among political parties protect against famines. ${ }^{45}$ Further, compared to the alternatives, democratic arrangements have better mechanisms for ensuring that authorities reliably, fairly, and effectively govern, and provide public assurance that such is the case.

Democratic contestation for legislative and executive power is a central mech-

43. Føllesdal \& Hix, supra note 12, at 547-49. See generally Robert A. Dahl, On Democracy (1998).

44. See Charles R. Beitz, Political Equality 113 (1989); cf. Margaret Levi, A State of Trust, in Trust and Governance 77, 94-96 (Margaret Levi \& Valerie Braithwaite eds., 1998).

45. E.g., Amartya Sen, Democracy as a Universal Value, J. Democracy, July 1999, at 3, 7-8. 
anism in this regard. ${ }^{46}$ Such contestation creates incentives that align the interests of the subjects to those of their rulers so as to ensure that the rulers are and remain responsive. Real political party contestation and critical media are crucial before, during, and after contestation. When parties form their policy platforms they help socialize citizens toward various conceptions of fair policy platforms. Political parties thus contribute to citizens' informed preference about feasible public policies and promote concern for others. In multilevel political orders this is particularly important and difficult, and careful regulation of multilevel party formation may help develop the requisite concern for citizens in other subunits.

Contestation and scrutiny are also crucial when citizens and parties seek to assess the record of the government in power and the plausible alternatives. Public scrutiny by the media and the opposition also helps ensure that power is not abused. Ultimately, contestation and scrutiny help render the institutions and authorities trustworthy. These contributions of democratic deliberation and contestation are important reasons to value democracy.

\section{Responses to Objections to Democratizing the Global Constitution}

The present reflections have so far laid out some reasons why the global constitution should be democratic. I now turn to reconsider some of the central arguments against such democratization, which were drawn from the ongoing debate about the need for a more democratic EU. The discussions about the direct and indirect impact of the global constitution, the multifarious forms of common interests institutions may secure, and the reasons for valuing democracy help to address the application of similar objections against a more democratic global constitutionalism.

\section{A. The Low Impact of the Global Constitution Beyond the State}

Against this objection I submit two points about the global constitution's degree of impact and its perceived salience for voters. First, global constitutional law has both indirect and direct impact on individuals, and currently diminishes many states' ability to protect and promote their citizens' interests. This impact supports the claim that individuals should influence these rules. Second, this claim cannot be rebutted by observations that voters in fact currently show little

46. See V. O. Key, Jr., Public Opinion and American Democracy 459 (1961); Joseph A. Schumpeter, Capitalism, Socialism, and Democracy 282-85 (Harper Collins 2008) (1941). 
interest in these issues. Of course, anti-globalization protests would make such objections immediately dubious. But I also submit that what we as citizens perceive as important is largely determined by the institutions that surround and shape us. The salience of a policy issue is thus partly endogenous to the political process - whether political parties and media choose to "mobilize bias." ${ }^{\text {.47 }} \mathrm{W}$ ith more political contestation at the international level, we can expect more attention to the direct and indirect effects of the global constitution as a whole, and of particular international organizations and regimes. Currently, contested issues include the complex impact of global economic liberalization. Thus, democratic contestation at the international level may shed light on the effects of complex interdependence and help determine what, if anything, might and should be done.

\section{B. The Objectives of Multilevel Regulation Prohibit Democratic Accountability}

There may be good reasons to keep some international agencies outside direct democratic control. Similar to some domestic agencies, this would combat coordination and commitment problems, or protect minorities against mistaken majoritarian decisions. Thus, unaccountable courts and agencies may be normatively legitimate even though they are not held directly or indirectly accountable to a democratically elected legislature. ${ }^{48}$ But these concessions do not counsel the wholesale rejection of democratic control over the global constitution.

First, Part III argued that other regulations in pursuit of other common interests still raise important distributive questions, even when they singly or jointly are Pareto improvements. Second, the global constitution must address the issue of trustworthiness. It does not suffice to show that particular independent bodies now pursue Pareto improvements. There must also be mechanisms in place to ensure citizens that these independent authorities can be trusted over time. In the domestic cases of independent agencies, central banks and courts are embedded so that they still largely operate in the shadow of democratic scrutiny and accountability ${ }^{49}$ This objection to democratic accountability should thus instead lead us to look for ways that the global constitution as a whole can be subject to

47. E.E. Schattschneider, The Semi-Sovereign People: A Realist's View of Democracy in AmErica 30 (1960).

48. See generally Andreas Føllesdal, Why International Human Rights Judicial Review Might be Democratically Legitimate, 52 Scandinavian Stud. L. 103 (2007).

49. Marlene Wind, Associate Professor, Centre for European Politics, Univ. of Copenhagen, The Nordics, the EU, and the Reluctance Towards Supranational Judicial Review, Presented at the Conference on Global Constitutionalism: Processes and Substance (Jan. 18, 2008). 
democratic scrutiny, deliberation, contestation, and accountability while allowing some select agencies or organizations within it to operate independently, while maintaining the public trust that they pursue the common interest.

\section{Multilevel Democracy is Unnecessary for Preference Policy Congruence}

Finally, with regard to the objection that democracy is not needed to ensure the requisite congruence between citizens' preferences and particular policies, I submit three comments. First, we must insist that the empirical question is not only about the particular track record of one policy, but also the choice of decision-making arrangements. We wish to determine the reliability of alternative mechanismswhether citizens can be given reasons to believe that these arrangements will reliably maintain acceptable regulations and policies is important. For democratic arrangements, this might be expected because party contestation for votes helps to hold the executive and legislative bodies sufficiently responsive to the best interests of voters. It remains to be seen what other, nondemocratic, institutionalized mechanisms might be put in place to render authorities trustworthy in their future policies.

Second, congruence between preferences and policies is not enough. Citizens' preferences are not determined in a manner completely exogenous to the political process, but are partly shaped by the opportunities, alternatives, and constraints that the authorities present, whether they are nondemocratic or democratic regimes. That citizens are satisfied in nondemocratic, or even dictatorial political orders, is of little normative significance if their preferences are not formed on the basis of informed deliberation about the range of possible policies and their likely effects.

Third, this objection underplays the other reasons to value democracy beyond its role in aggregating the input of preferences. Even if there are alternative decision mechanisms that reliably make authorities responsive to citizens' preferences, an important further concern is that citizens should be assured that this is in fact the case. Such assurance is often important to secure general compliance. ${ }^{50}$ Democratic procedures, especially opposition parties and media scrutiny, play important roles in this regard. Alternative competitors for political office with competing policy agendas help citizens determine whether their present leaders could have done better and identify who is responsible for specific policies. This in turn provides assurance to citizens that their leaders are sufficiently responsive. And public knowledge thereof enhances politicians' incentives to remain so.

In conclusion, present reflections have bolstered the case for why the global con-

50. See Føllesdal, supra note 10, at 454-59. 
stitution should include mechanisms that would make it more democratically accountable toward citizens. I identified some of the central arguments for and against such democratization, drawing largely on the ongoing debate about the alleged need for a more democratic EU.

I have also outlined some reasons why decisions at the international level both about the design and authority of international organization and regimes and their own decision-making processes--have important consequences. In domestic settings, such distributive conflicts give rise to challenges of normative legitimacy, to which democratic arrangements are often regarded as one acceptable response. I have considered and rejected some prominent objections to the need for democratic accountability of this global constitution. I believe that the arguments drawn from the debate about the EU do not stand up to scrutiny when applied to global constitutionalism. The normative claim of global constitutionalism holds up: If the international legal order is to be justifiable to us, its subjects, core constitutional principles of democracy should be brought to bear. 